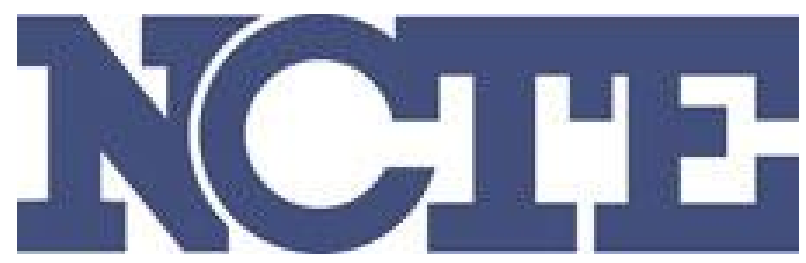

The National Endowment for the Inhumanities

Author(s): Richard Kostelanetz

Source: College English, Vol. 39, No. 5 (Jan., 1978), pp. 595-602

Published by: National Council of Teachers of English

Stable URL: http://www.jstor.org/stable/376120

Accessed: 09-08-2016 17:04 UTC

Your use of the JSTOR archive indicates your acceptance of the Terms \& Conditions of Use, available at

http://about.jstor.org/terms

JSTOR is a not-for-profit service that helps scholars, researchers, and students discover, use, and build upon a wide range of content in a trusted digital archive. We use information technology and tools to increase productivity and facilitate new forms of scholarship. For more information about JSTOR, please contact support@jstor.org.

National Council of Teachers of English is collaborating with JSTOR to digitize, preserve and extend access to College English 


\section{The National Endowment for the Inhumanities}

The development of this public agency is itself a demonstration of national values in action. It is concerned with the support of intellectual life-and with the moral debt we owe to the founders of the Republic. The one implies that professional research of the bighest quality be supported; the other that this be done for some useful and general purpose.-Ronald Berman, Ninth Annual Report, National Endowment for the Humanities (1975).

Not UNLIKE HUNDREDS of other American scholars, I have applied for support to the National Endowment for the Humanities, dutifully volunteering the requested information and making all the stipulated photocopies. My proposed project has been a critical study of innovative American literature since 1959; and within the application itself, I announced that, as my criteria of selection are formalist, I would be concentrating on such radical literary alternatives as visual poetry, sound poetry, innovative syntaxes, linguistic minimalism, and artificial languages. Then and now, I use these terms less as critical categories than as convenient descriptive handles that, though they are reductive, have the advantage of separating my chosen terrains from everything else. To lend substance to these terms, I also named the writers I expected to discuss under each category, as I knew that their names were probably not common currency, even at the National Endowment for the Humanities.

In my application, I also noted that my proposed project, which I tentatively called "The New Literature," grew out of the penultimate chapters of my critical book, The End of Intelligent Writing (1974), and that certain general ideas about innovative literature were broached in my introductions to the anthologies Possibilities of Poetry (1970), Imaged Words \& Worded Images (1970), Future's Fictions (1971), Breakthrough Fictioneers (1973), and Essaying Essays (1975), as well as in my earlier critical book on The Theatre of Mixed Means (1967) and several critical essays published in American magazines. Several reviewers of The End of Intelligent Writing kindly identified me

Richard Kostelanetz, born in New York in 1940, bas recently been a Visiting Professor at the University of Texas at Austin. His book The End of Intelligent Writing bas been reissued in paperback under its subtitle, Literary Politics in America. In September Wordsand, a retrospective of bis creative work, will open at Simon Fraser University prior to touring.

College English

Vol. 39, No. 5 - January 1978 
as the principal serious critic of this experimental literature, and a few even hoped that I would develop the sketchy surveys of its chapters on "The New Poetries" and "Innovations in Fictions, Dramas, Essays." Back in 1973, when I first applied to the Humanities Endowment, I thought my chances good, not only because the project seemed culturally useful-an updated Axel's Castle, so to speak-but also because its new director, Ronald Berman, had praised my criticism in his own book on America in the Sixties (1968), and had written sympathetic personal letters to me about The End of Intelligent Writing.

Nonetheless, not unlike hundreds of others, I found my application rejected by the NEH-not only in 1974, but in 1975 and then again in 1976. "Since the applications were reviewed and evaluated on a competitive basis," Berman's most recent letter ran, "the inevitable result was that many worthy candidates could not be selected to receive fellowships. Please be assured, however, that your application was very carefully considered. All of the applications that we received were evaluated by highly trained specialists and broadly educated humanists who devoted many days to this task."

Only recently did I come to examine the latest annual reports and press releases of the Humanities Endowment. In them I discovered, to my dismay, that no one known to me to be doing scholarly-critical work on experimental American literature, present or past, has recently received a fellowship from the NEH. Now, of course, it would be presumptuous of me to expect to know the name of every scholar in my chosen field, but I think I know enough names (and have been observed to have a voraciously encyclopedic memory for my profession's names) to conclude with some authority: even though most of the greatest American literature has been formally experimental in crucial respects, scholar-critics doing work on this theme rarely, if ever, receive support from the National Endowment for the Humanities. The kind of advanced literary research encouraged by European agencies is given absolutely no government support here. This egregious neglect is not just pathetically unsophisticated, by international standards: it is also profoundly and shockingly unAmerican. In our Bicentennial years, it is distressing to see such blatant betrayal of our revolutionary traditions at our government "humanities" agency; the founding fathers of our cultural heritage must be fuming in their graves.

Rechecking the NEH winners list for the past two years, I made a second, different, appalling discovery. I could not find the name of any scholar-critic of either art or literature, under forty, who had already done major work on any subject-not just on American experimental writing but on anything at all in art or literature. There were, to be sure, the names of older scholar-critics (Lionel Trilling, Alfred Kazin), and I could find a few young scholar-critics whom I knew well enough to know that they have not published any major books, let alone much; but I could not identify anyone who had. Since I had recently edited and introduced an anthology of Younger Critics in North America (1976), I think I can claim expert familiarity with the populace of this terrain. Indeed, the NEH's own lists of winners suggest that young scholar-critics who had not published any major works had a far better chance than those who had, and that 
fact in turn suggests that the NEH selection committees place a low "value" on prior achievement, at least in their selection of younger people.

In a second NEH booklet, entitled Program Announcement 1976/1977, I discovered the following explanation of its selection procedures:

$[\mathrm{NEH}]$ grants are awarded competitively and on individual merit, following a careful review process. All applications are reviewed individually by professionals outside of the federal government and judged in competition with one another within each program by non-federal panels. Four times a year, the National Council of the Humanities, an advisory council appointed by the President of the United States, meets to consider all applications, along with reviewers' and panelists' comments. During Council meetings all applications and review summaries are considered within Council committees and finally brought before the full Council for its recommendations. The Chairman of the Endowment ... makes the final decision on each proposal after receiving the Council's recommendation, and notifies the applicant of that decision.

A few pages later, the anonymous booklet-writer explains that

... fellowships [for Independent Study and Research] are intended for scholars, teachers, writers and other interpreters of the humanities who have made, or demonstrated promise of making, significant contributions to humanistic knowledge.

However, the evidence already cited suggests that certain kinds of prior contributions, or those from certain kinds of people, simply count for naught at the NEH.

The processes of cultural granting are ultimately not as mysterious as they initially seem. The first rule is that the character of the winners invariably reflects the character of the judges: a related rule is that if certain interests are not represented in the selecting panels, applicants exhibiting those interests will likewise be completely excluded from the rewards. In practice, most fellowship judges tend to support applicants roughly like themselves-in age, racial-ethnic background, professional commitments, and intellectual persuasion. This is not unexpected, and probably unobjectionable as well, as long as a true diversity of indigenous interests is represented on every grants-jury.

Checking the Anmual Report's list of NEH panelists ("professionals outside of the federal government"), I noticed, first, the complete absence of major younger scholar-critics and, second, a similar absence of anyone sympathetic to and knowledgeable about the New Literature I wished to study. The closest possible exception to the second omission would be Hugh Kenner, whose favorable review of The End of Intelligent Writing (National Review, May 23, 1975 ), nonetheless revealed that his own sympathies stretched little further than the initial generation of post-Poundian poets, Louis Zukofsky and George Oppen. And that obviously was not far enough for what I now had in mind. I could find no close exceptions to the first omission.

The NEH self-description tells me that if any application gets past this initial pool of panelists, it would go to a Council subcommittee and then to "the full Council." That scenario sent me back to the Tenth Annual Report (1976), but 
whereas Berman speaks of twenty-six members on page 8 , I found only sixteen names on page 66. This list from its misspellings is not uninteresting as an index of "values in action," to remember Berman's phrase:

Those with terms expiring in 1978:

Dr. Hanna Holburn [sic] Gray, Provost, Yale University

Dr. Jeffrey Hart, Professor of English, Dartmouth College

Dr. Sidney Hook, Professor of Philosophy, New York University

Dr. Martin Kilson, Jr., Professor of Government, Harvard University

Mr. Irving Kristol, Professor of Urban Values, New York University

Mr. Richard R. St. Johns, Richard R. St. Johns \& Associates,

Consulting/Management, Santa Monica, California

Mr. Sheldon H. Solow, President, Solow Building Corp., New York, NY

Dr. Frank E. Vandiver, Provost, Rice University

Those with terms expiring in 1980:

Mrs. Howard F. Ahmanson, Los Angeles, CA

Mr. Ted Ashley, Chairman of the Board, Warner Bros., Burbank, CA

Honorable Louise [sic] Alberto Ferre [sic], Former Governor of Puerto Rico

Mr. William A. Hewitt, Chairman and Chief Executive, John Deere \& Co., Moline, IL

Dr. Robert Hollander, Jr., Professor in [sic] European Literature, Princeton University

Dr. Truman G. Madsen, Professor of Philosophy, Brigham Young University

Dr. Robert A. Nisbet, Professor of Humanities, Columbia University,

Mrs. John D. Rockefeller, 3rd., New York, NY

Four of these sixteen appear to be businessmen whom I could not find listed in Who's Who in America (Ashley, Solow, St. Johns, Hewitt); one wonders how their names came to the attention of the NEH (and yet evaded the ever-solicitous Marquis Co.). A fifth (Luis Ferré) is less a civil servant than the former proprietor of Puerto Rico's largest cement company. Two Council members are culturally active wives of very rich philanthropists. Four are politically conservative polemicists (Hart, Hook, Kristol, and Nesbit). None whom I can publicly trace was born after 1931 except Kilson, who also appears to be the sole black.

Since writing the above paragraph, I have received a press release naming nine more "distinguished citizens":

Durwood Belmont Varner, President of the University of Nebraska

Nancy Davis, member of the Oklahoma Humanities Committee

John Hope Franklin, Professor of History, University of Chicago

Jay Gordon Hall, Director of Government Relations, General Motors, Washington, DC

Richard Wall Lyman, President of Stanford University

Concha Ortiz y Pino de Kleven, Albuquerque, NM

Eugene Smith Pulliam, President and Publisher of the Indianapolis News and Star

Joe Bob Rushing, Chancellor of the Tarrant County Junior College District, TX

John Walton Wolfe, Chairman of the Board of the Columbus Dispatch

In sum, to the supreme Council were added three academic chiefs, two news- 
paper publishers, two old-style political hens, a military-industrial lobbyist, and one token bona fide scholar, all of whom were also born before 1930 .

Anyone aware of the plurality of American culture can see that this appointed panel is a scandalously unrepresentative crew, stacked to the political right and to age against youth. Were we not otherwise informed, we would think these "distinguished citizens" were trustees of a right-wing think tank, or a retreat for retired academics, or a high-faluting school desk company. (Perhaps the NEH is a front for something else.) The thought of getting stuck with them on a sinking ship would give most of us scholarly applicants nightmares. What, aside from money and retirement, could we talk about? Few of us are assured by the notion of these people annually controlling $\$ 73$ million (73 million bucks!) that could influence the cultural future of the United States. Together, they discredit both each other and themselves, leaving us questioning, first, how culpably conscious each is of their collective character and, then, if any of them has ever protested the company that the NEH asks him or her to keep? Do they understand what they are doing? And how their names and reputations are being exploited? Do they know why they, rather than others, were chosen? Or are they sonambulists simply too smug to care, or to care whether anyone else cares? Can they be held publicly accountable? Are minutes kept of their deliberations? Can these be made public under the Freedom of Information Act? Can we ask that the next application booklet contain mug shots so that we applicants can see what kinds of human faces lie behind these names and imposing titles? Can we interview the Council in a public session? Can their future meetings be videotaped for national distribution? Does their "distinguished" citizenship include responsibility to us?

I for one would honestly have more confidence in an NEH Council composed, say, of a random sample of readers of this magazine, or, say again, of Howard Cosell, Alex Karras, Muhammad Ali, and Billie Jean King. At least, their decisions would be less deleterious.

One job for the Carter administration will be flushing out the hidden legacies of the Nixon-Ford years.

As for my own application, it appears that only one supreme Councilor (Hollander) would have even minimal awareness of what I proposed to do; but I doubt if it ever got to him. By now I suspect that the unidentified lower panel initially "evaluating" my application was just as stacked as the NEH superpanel. Indeed, it is reasonable to assume, given no evidence to the contrary, that all first-level NEH panels in every field are similarly stacked. (And one wonders how conscious these panelists are of the NEH jury-rigging?) If an application is not supported at this initial level, it does not get to first base; and as all ballplayers know, unless you get to first, you cannot get to second; and if you cannot get to second, you'll never have a shot at home. Since Ronald Berman is himself a scholar-critic of literature, who published major books before he turned forty, the omission of accomplished young people from all NEH levelsthe Council, the panels, and the general recipients list-was not only surprising but also ominously strange. My personal disappointment in him is tempered by 
my reluctant realization that $o d d$, to be sure, is the intellectual with no desire to encourage the replication of his own kind.

Since proving the omission of certain kinds of people is considerably riskier than observing their presence, I invited James Blessing, the NEH director of fellowships, to refute my suspicions. His written answer provides a vivid index of both the state of literary literacy at the $\mathrm{NEH}$ and its sensitivity to the exclusions I noticed:

Several of this year's Fellows are doing critical work on contemporary American literature I will leave it to you to decide whether their work falls within the realm of experimental literature. James Breslin, who is 41 years old, will be doing a book on contemporary American poetry; Austin Quigley (34) plans to do a study of post-1950 theater in relation to its precedents; Arnold Rampersad (35) is preparing a history of Afro-American poetry, including "a serious attempt to place the outpouring of verse in the last few years in the context of the black American literary tradition"; and Mas'red [sic] Zavarzadeh (38) will be studying a radical form of recent American innovative fiction which he calls "metafiction.'

To any reader who has followed me so far, it ought to be quite clear that none of these, except perhaps Mas'ud Zavarzadeh, is interested in innovative writing, as defined in my application; and none of these people had, prior to 1977, published anything which could be regarded as major work.

Then, putatively to refute my suspicion that certain classes of scholar-critics were excluded from the selection panels, Blessing replied with these names: "Charles Altieri, Wayne Booth, John Cawelti, Ruby Cohn, Richard Gilman, Hugh Kenner, Edith Kern, Barbara Herrnstein Smith, and Brom Weber." Everyone on this list is familiar to me; two published my criticism when they were editing magazines. If any of these "highly trained specialists and broadly educated humanists" is more informed about the New Literature than Hugh Kenner, they have kept that knowledge to themselves; and none of them except Altieri (the author of a few articles) is presently under forty. In short, Blessing's "reply" demonstrates that not even the director of individual fellowships at the $\mathrm{NEH}$ could refute my charge of blanket exclusion of both my categories from the selection panels and, thus, the winners list. Someone might object to these categories as artificial, but the fact that individuals belonging to them were indeed totally excluded makes such terms essential to analysis. Jews did not become a stigmatized minority until a society made it a practice to exclude them.

To repeat, if proponents of certain kinds of cultural endeavor are excluded from the selection juries, no one should be surprised-least of all the professionals at the NEH - that people doing such work are totally excluded from the spoils. Nor should NEH officials be surprised if members of excluded groups cease to apply to it, as most of us are justifiably reluctant to run races that are from the start stacked against us. Nonetheless, foundation officials typically cite "lack of applications," as indeed Mr. Blessing did privately to me, as "evidence" of lack of interest in experimental literature. No, the lack of applications from a constituency known to exist actually indicates that the machinery of discourage- 
ment has been effective. The sweepstakes were as "competitive" as Berman promised, but it was from the beginning, to repeat again, rigged against my cultural kinds. Any cunning, narrow-minded cultural commissar can stack a panel to insure that certain sorts win and other sorts lose (and that funds are squandered), but selecting a panel representing a diversity of American excellences (and spending public money well) requires more cultural intelligence than, to judge from the evidence, has recently been present in some operations of the National Endowment for the Humanities.

When the admissions board of an organization has no Jews (or no women or no blacks), it is scarcely surprising that the membership has no Jews (or no women or no blacks) either. However, one difference between the Humanities Endowment and a private country club is that the former is a tax-funded organization congressionally directed to support cultural quality in the United States; it is responsible to the American public, which is to say US. As cultural agencies have discovered from their confrontations with militant blacks and women, the surest way to assure neglected groups of a chance for reward is to include its representatives not only among the winners but among the judges as well.

It has become clear to me that the amount of work I have already done and the recognition it has received, combined with my age and my chosen subject, disqualified me from an NEH Senior Fellowship; and since the NEH selection boards are composed of older power-people, it is also apparent that, at least in their awards to younger people, they prefer "promise" to achievement, which is another way of saying attentiveness to accomplishment and flattery to "the highest quality." Such bias is not "elitism," the best favoring the best, all pressagentry to the contrary notwithstanding, but something less, much less. The $\mathrm{NEH}$ competition is not the real professional world of peer review but the graduate school hothouse all over again-the old boys picking the kids they like best. Everyone knows that this attitude is conducive to work that is not superior but "acceptable," which is to say passable.

It would be equally wrong for different $\mathrm{NEH}$ administrators to exclude older people from the panels (and thus let only kids choose the old boys the kids like best). Nonetheless, a dangerous precedent has already been set, one kind of ageist exclusion justifying another.

The lack of support for excellences that are young and experimental suggests on its face a desire to sabotage what is best in American culture-to kill off its rejuvenating forces, rather than nourish them; one ominous conclusion is that these NEH selection procedures are quite explicitly rigged against the future. At first I suspected that insidious closet Communists had infiltrated the NEH house, but the composition of the Council suggests, instead, the dominance of a persuasion that is philosophically opposite and yet in certain effects precisely similar-reactionary utopians, who would create a world blissfully free of change (e.g., experiment and accomplished young people). Either way, we find evidence of a persisting sixties radical philistinism that believes in terminating the best American cultural traditions, rather than in extending them; this is not "humanities" but inhumanities. 
"The New Literature" is scarcely the only example of something that such agencies would prefer to suppress, and one unfortunate secondary effort of exposing their blanket inadequacies, as I am doing now, is making it even harder for some of us to go on. The tragic truth might be that the National Endowments, say, are as often discouraging of effort, if not excellence, as encouraging. Thus, there is good cause for outside investigators-inevitably ourselves-to make a survey of the kinds of possible researches that are never funded and why. And what does not happen for the lack of necessary funds? And what are the social and cultural costs of such defaults? Once such omissions are recorded and the cultural losses measured, we can get a better idea of not only the frauds of our National Endowments but also of what changes should be made. Meanwhile, let me suggest that those similarly aggrieved in their dealings with a federal agency might have sufficient evidence for a class action suit.

One reason why so little criticism of the $\mathrm{NEH}$ and other granting agencies appears in public print is that those most likely to be aware of their deficiencies are disappointed applicants seduced by the starry-eyed hope that they may someday be beneficiaries. (That gang no longer includes me.) A second reason is that periodical editors often serve as panelists for granting agencies, who can then incidentally assure themselves that criticism of their foundation will probably not appear in that editor's pages. In general, those who make cultural selections for an organization larger than themselves have an obvious vested interest in keeping all cultural selection processes unexamined. A third reason is that publicly appearing disgruntled or bitter is an image that few of us invite.

Nonetheless, one of my ulterior motives in writing this critique is overcoming the "nigger" mentality that would lead me to envy the fellowship winners rather than confront the slave merchants. Personal feelings and hyperbolic style notwithstanding, this essay deals with real issues and real fears-with the raising of consciousness and the procedures for accountability.

Meanwhile, it is sad for me to acknowledge that I and others like me wasted much too much mental energy (and photocopy money) in pursuit of illusions. 